\title{
The Changing Nature of Information Work in Museums
}

Paul F. Marty

College of Information

Florida State University

marty@ci.fsu.edu

\begin{abstract}
This paper presents results from twenty-one semi-structured interviews with museum information professionals (MIPs) who were asked about their experiences working with information resources, tools, and technologies. Interviews were analyzed to determine 1) the challenges MIPs face as they adapt to changing technical capabilities and strive to meet the changing needs and expectations of museum users; and 2) the coping mechanisms MIPs employ on the job that enable them to deal effectively with those challenges. The paper presents the results of this analysis, exploring how MIPs cope with the changing nature of information work in museums by relying on thirteen different strategies, including assessing new technologies in relation to the museum's core mission, helping museum professionals embrace new ideas about information access and provision, and promoting internal practices that encourage the sharing of information and the integration of information science into museum work. The paper discusses the implications of these challenges and strategies for current and future MIPs, and assesses their impact on changing perceptions, roles, and research for information professionals in museums as they work to meet the information needs of all museum users.
\end{abstract}

\section{Keywords}

Museum informatics; museum information professionals; information work in museums.

\section{Notice}

This is a preprint of an article accepted for publication in the Journal of the American Society for Information Science and Technology. Changes resulting from the publishing process, such as peer review, editing, corrections, structural formatting, and other quality control mechanisms may not be reflected in this document. Changes may have been made to this work since it was submitted for publication. The final version of this article was published in the Journal of the American Society for Information Science and Technology, 58 (1), 97-107. http://dx.doi.org/10.1002/asi.20443 


\section{Introduction}

Information professionals working in museums today face many challenges, as information resources become more technically-complex, and the users of those resources become more information-savvy. Over the past decade, the needs and expectations of museum professionals and museum visitors have become increasingly sophisticated; no longer satisfied with limited access to information about museum collections, many desire twenty-four hour access to museum data, no matter where those data are located, or how these data are organized (Cameron, 2003; Hamma, 2004a; Knell, 2003; Rayward, 1998). Meeting the changing needs and expectations of museum users has necessitated the use of complex technologies for organizing museum information, presenting a challenge for information professionals in museums (Hamma, 2004b; Marty, 2004b).

To cope with this challenge, researchers have explored the interactions between people, information, and technology in museums, an area of study known as museum informatics (Marty, Rayward, \& Twidale, 2003). Museum informatics has become increasingly important as advances in information science and technology offer new capabilities to help museum professionals meet changing user needs. Researchers have explored such topics as metadata standards for data sharing initiatives (Coburn \& Baca, 2004; Perkins, 2001), techniques for analyzing the use and usability of museum websites (Cunliffe, Kritou, \& Tudhope, 2001; Marty $\&$ Twidale, 2004), and methods for assessing user needs and expectations (Goldman \& Schaller, 2004; Kravchyna \& Hastings, 2002).

At the same time, a new type of museum professional has evolved, one who specializes in the application of information science and technology in museums, and whose interests lie in managing the unique information resources found in museums (for a detailed analysis of the evolution of this new museum professional, please see Marty, in press). Operating under such titles as "information manager," "information technology specialist," or "chief information officer," these museum information professionals (MIPs) bring valuable skills to the modern museum. Despite their importance for today's museums, little is known about the roles these individuals play; MIPs are among the least studied of all consumers and producers of museum resources (cf. Gilliland-Swetland and White, 2004).

To increase understanding of MIPs, this paper presents results from semi-structured interviews with twenty-one information professionals working in museums, who were asked about their experiences working with information resources, tools, and technologies. Interviews were analyzed to determine the challenges MIPs face on the job, as well as the strategies or coping mechanisms they use to operate successfully in an information-rich environment. This paper presents the results of this analysis, exploring how MIPs cope with the changing nature of information work in museums and adapt to meet the needs and expectations of all museum users.

\section{Literature Review}

Museum professionals, like professionals working in most information organizations, have a history of working with information resources, tools, and technologies. In some sense, all museum professionals can be considered information professionals, as information management 
skills have always been important for museum professionals (Lord \& Lord, 1997; Orna \& Pettitt, 1998). Museums are in the midst of an information revolution, and museum professionals must work with a variety of different information resources, from the museum's collections themselves, to information about those objects, to information about the contexts in which those objects are displayed, studied, or interpreted (Knell, 2003). The need to provide access to information is well known within the museum community (Washburn, 1984). The past few decades have seen an important shift from the idea of museums as repositories of objects to museums as repositories of knowledge (Cannon-Brookes, 1992; Hooper-Greenhill, 1992; cf. White, 2004); the museum has truly become an information utility (MacDonald, 1991).

As part of this process, certain museum professionals have developed sophisticated information management skills. The traditional careers of museum librarian or registrar provide exemplars of museum positions that require experience with information resources (American Association of Museums, 1994; Burkaw, 1997; Danilov, 1994; Glaser \& Zenetou, 1996; Schwarzer, 2001a). The skills these individuals bring to the museum are well-documented (Case, 1998; Koot, 2001; Reed \& Sledge, 1998). In recent years, a new type of information professional has emerged in museums (Grant, 2001; Hamma, 2004b; Roberts, 2001). Museum researchers and practitioners have been discussing the emergence of and need for this role since the mid-1990s:

Perhaps there is a new role in museums for an 'information manager' who is charged with caring for the museum's information. [...] Few, if any, museums have a staff position with this title now, but the function will become increasingly important as we integrate information systems into our daily work. (Hermann, 1997, p. 75)

The evolution of this new role has coincided with the growing importance of museum informatics (Marty, Rayward, \& Twidale, 2003; cf. Marty, 1999). Museum professionals are increasingly concerned with meeting user needs and ensuring that the right information resources are available at the right time and place, whether users are inside or outside the museum (Marty, 2004b). To accomplish these goals, museum professionals spent the past decade learning about such things as metadata schemas and controlled vocabularies for museum information resources (Bearman, 1994; Lanzi, 1998), distributed collection building and data sharing initiatives (Allen, 2000; Bennett \& Sandore, 2001; Rinehart, 2001), and information policy and digital rights management (Bearman, 1997; Blackaby, 1997; Carson, 2001; Zorich, 1999).

The challenges of museum informatics are not the same as those posed by museum librarianship or museum registration. While there is considerable overlap, museum informatics is a unique field of study requiring its own, substantially different, educational background and career path (Marty, 2005). The success of museums will depend largely on the work of information professionals specifically trained to deal with the problems of museum informatics and the museum's information needs (for a detailed treatment of the roles and responsibilities of MIPs, see Marty, in press). As Hamma (2004b) writes, "Adding information management as an integral part of a museum's routine activities will or should change the organization with the addition of at least some new staff, new skill sets and a new management effort" (p.12).

A number of researchers have conducted studies to provide valuable data about the information needs, seeking, and behavior of the typical users of museum information resources, both in the 
museum (Economou, 1998; Evans \& Sterry, 1999; Galani \& Chalmers, 2002; Schwarzer, 2001b) and online (Chadwick \& Boverie, 1999; Goldman \& Schaller, 2004; Ockuly, 2003; Sarraf, 1999). By understanding the needs of museum visitors, MIPs can better serve their clientele (Cameron, 2003; Müller, 2002; Teather \& Wilhelm, 1999; Zorich, 1997). By evaluating the steps they are taking to meet the needs of their users, MIPs can help ensure a positive relationship with museum users (Gillard \& Cranny-Francis, 2002; Harms \& Schweibenz, 2001; Hertzum, 1998).

Researchers have no shortage of topics from which to choose when studying museum informatics (cf. Bearman \& Trant, 2000). Coburn and Baca (2004) looked at how different metadata schemas help or hinder users seeking collections data from museums. Hamma (2004a) examined the changing expectations for online museums engaged in outreach to many different audiences. Bowen and Filipinni-Fantoni (2004) explored different methods of targeting individual user needs through personalization and pervasive computing technologies inside and outside the museum. Cameron (2003) studied how the ability to help museum visitors conceptualize information resources transformed the way museum professionals build relationships with their users. Dyson and Moran (2000) discussed the importance of creating accessible and usable information resources for online museum projects. Cunliffe, Kritou, and Tudhope (2001) explored different methods for determining whether museum websites meet the needs of their users, and discussed the dangers of not evaluating museum websites for usability. Peacock (2002) discussed statistics and transaction log analysis for museum professionals interested in evaluating user satisfaction with museum websites. Kravchyna and Hastings (2002) discussed the importance of understanding the information needs of their users at all stages of a museum visit, including access over the internet before and after physical museum visits.

There is no doubt that these (and many other) studies have the potential to be extremely useful for museum information professionals struggling to meet the changing needs and expectations of their users worldwide. Few studies, however, have focused on the nature and behavior of MIPs themselves. Bernier and Bowen (2004) evaluated the information behaviors of museum professionals online, in particular their use of online discussion forums. Gilliland-Swetland and White (2004) studied the ability of MIPs to use metadata standards that provide access to museum information online. Marty (2004b) discussed the changing role of MIPs as technologies change, and these individuals adapt their work practices to coincide with these new technologies (cf. Marty, in press). Haley Goldman and Haley Goldman (2005) explored web development as a profession in museums, interviewing museum webmasters and asking about their work, their sources of inspiration, and their ideas about the future of museum website design (cf. Marty, 2004a).

The current state of knowledge about MIPs pales in comparison to knowledge about museum users. Particularly lacking is research that will help us understand how MIPs are adapting to meet the challenges of museum informatics. As with many information professionals, very little is known about how MIPs characterize their own work, the challenges they face, and the strategies they employ. To guide future research in museum informatics, it would be helpful to understand how perceptions of museum information work are changing from the MIP perspective. The best way to understand this is to ask MIPs about the challenges they face and the coping mechanisms they employ as they meet information needs in the modern museum. 


\section{Research Questions and Methods}

This paper presents results from an exploratory study designed to address the following research questions: 1) What challenges do MIPs face as they adapt to changing technical capabilities and strive to meet the changing needs and expectations of museum users? 2) What coping strategies do MIPs employ that enable them to deal effectively with those challenges while making use of information resources, tools, and technologies on the job?

To answer the research questions, semi-structured interviews were conducted with twenty-one research participants recruited from various national and international museum conferences where attendees are interested in museum informatics. Given the lack of any existing registry for MIPs, it was determined that advertising this study at conferences likely to appeal to such individuals was the best way to locate and recruit potential participants.

Research participants worked at 17 different museums in the United States, including five history or cultural heritage museums, one science and technology museum, eight art museums, two museums of natural history, and one children's museum. Although they varied widely in technical skills and expertise, all participants were responsible for managing information resources, tools, or technologies in some fashion. Participants ranged from lower-level positions to middle-managers to high-level administrators, having anywhere from one to 30 years of experience in the museum field. They came from diverse backgrounds and held a wide variety of jobs: four participants worked primarily as information and communication technology specialists in museums, nine worked primarily as webmasters or new media specialists, six worked primarily as project managers (typically holding titles such as curators or educators), and two were high-level administrators such as Chief Information Officers. For a detailed analysis of the types of jobs held by the participants, please see Marty (in press).

Participants were asked several questions about what they do daily, what skills they need to perform their jobs, and how these skills have changed over time. As participants described their daily tasks, additional probing questions were asked to explore in detail the challenges MIPs face, and how they dealt with those challenges. Participants were asked such questions as:

- How long have you worked in the museum field? How long have you worked at your current position? What is your current job title and job description?

- Please describe for me a recent project you worked on. Is this a typical representation of what you do on a daily basis? Could you tell me a bit more about your daily activities?

- What skills would you say you need in order to perform your job well? Have these changed over time? How so?

- Do the projects you work on or are involved with demand growing levels of information skills? How so? How do you think people who work in museums today have changed to become more information literate than museum professionals in the past?

Interviews each lasted approximately an hour. They were transcribed completely and analyzed using grounded theory methodologies. Drawing upon the participants' answers to each of the above questions, a process of coding and memoing, as outlined by Strauss and Corbin (1998), was used to develop an understanding of problems faced by information professionals working 
in museums and the strategies they employ to solve those problems. This kind of analysis is an iterative, on-going process where participant responses are analyzed as part of a continual process of exploring the data to identify emergent themes and dimensions. A random selection of the data was also examined, using the final list of concept codes, by a second researcher. By studying the challenges faced by information professionals working in museums, understanding of how MIPs cope with the changing nature of information work was improved.

\section{Findings: Challenges and Coping Strategies for Museum Information Professionals}

From data analysis there emerged a set of coping strategies employed by MIPs as they faced the daily challenges of museum informatics. While individual participants employed different skills when implementing these strategies, the overall strategies themselves, as well as the overall challenges they faced, were common to the majority of participants. The results presented here, therefore, do not focus on specific skills shared by MIPs (research participants exhibited such variation in skills, backgrounds, and experiences that it was impossible to produce a list of skills that all participants shared). Rather, they focus on strategies identified by research participants as they described the challenges of information work in museums - an approach which accurately reflects the perspectives of research participants. Given the rapidity with which a list of specific skills for MIPs can become outdated, an emphasis on challenges and strategies was the only logical way of synthesizing and presenting the data gathered in this study.

The results are organized into three sections covering strategies employed by participants to meet the challenges of information work in museums. First, the paper explores how research participants face changing capabilities, as new technologies offer new opportunities for MIPs to meet user needs. Second, the paper explores how participants face changing needs, as users adapt their needs to meet the museum's new capabilities. Third, the paper explores how participants face changing expectations, as museum professionals and visitors adapt their understandings of the information museums should provide and the role museums should play in the information society. Each section is illustrated by quotes from the participants; participant numbers are included for cross-referencing, but all identifying information has been removed.

\section{Changing Capabilities}

Advances in information science and technology with the potential to affect the museum environment occur frequently. According to research participants, almost every day brings something new for MIPs to learn as they perform their jobs. Participants feel pressured to learn new information science and technology skills, in order to implement new capabilities as they become available. They stress the need to be constantly "moving forward:"

We're always moving forward here; the person who was hired five years ago, at that point in my life, I could not do the job that I'm doing now. Five years is a really long time as far as information science goes; we're really looking at a different environment now. [P07]

Technological advances offer MIPs new ways to meet user needs, encouraging them to try new methods of providing access to information for users. No longer limited, for instance, to static 
text that presents the same information to all users, MIPs experiment with new ways of providing personalized information to diverse users across multiple media. They search for the most effective way to organize and prepare information on the "back-end" so that related information resources can be dynamically disseminated on the "front-end:"

We're moving more towards databases underlying the information rather than constructing each page separately. We have to spend a lot of time thinking about what the underlying information is and how all of the different fields can relate, thinking about different ways it would be effective for them to disseminate this information. That takes a lot of work, trying to do that sort of thing on the back-end before you work on the frontend. [P01]

These new ways of working take time, and may result in unanticipated problems requiring even more time to solve. This is often the case with the implementation of new museum technologies, as many MIPs feel pressured to offer the latest technologies even if they do little to advance the museum's core mission. According to research participants, such worries become more pronounced as new technologies become more accessible, easier to use, and simpler to implement for even small, under-funded museums:

In technical capacity, websites have gone, in my opinion, from being actually very difficult to build, when people had to code things by hand, to very easy, like when all these simple web development programs came around, which created a whole problem that everyone thought they needed a website. [P20]

To cope with changing capabilities, new technological advances, and the related difficulties that follow their availability or implementation, research participants relied on several strategies. First, MIPs need to understand the potential impact of new capabilities on the museum. Central to this understanding is an ability to implement new information systems and solve technology problems. As museums rely more heavily on advanced information technologies to meet user needs, it is imperative that someone in the museum understands the value of new technologies for the museum, recognizes the importance of keeping the museum's technologies up-to-date, and knows how to solve problems as they occur:

Someone needs to be able to go in behind the scenes, so to speak, and configure things for institutions to use and to fix things when they break down, because they do. And when they come up with a new browser or a new and better version of Illustrator or whatever it is, you need someone there that it doesn't take, you know, 4000 hours for them to do something because that's their field of expertise, to be able to solve these things and figure out how to use them and that sort of thing. [P02]

Second, MIPs need to help others understand the value of new capabilities for the museum. As the information needs of museum users become more sophisticated, it is important that museum employees understand why and how they should use new capabilities in their daily work. MIPs play an important role in explaining new technical capabilities to others and ensuring that all museum professionals have the knowledge they need to make effective use of new technologies and new capabilities: 
I think that you need to have the ability to explain things to people and show them. If you just do it, they'll never learn it, so you need to be able to show them and have them go through the steps. [...] Occasionally you'll get questions where you can't answer it and you need to go research it and come back to them, but I think a solid knowledge of every application plus the ability to troubleshoot and explain the solutions are needed. [P11]

Third, MIPs need to keep current with changing capabilities. For research participants, staying up-to-date is very important if they wish to understand what can be done now and what will be possible in the near future. Only with that knowledge can MIPs be sure they are doing the best they can for the museum. While keeping current can be challenging, it can pay off:

I think staying up to date is the thing that I'm most concerned about. [...] I've kind of always got one eye out for what's the next new thing, or what's a better way to do whatever I'm doing. I'm always pushing myself in kind of taking what I'm in a habit of doing and creep it forward, but also keeping an eye on the future picture. It's probably the thing that I work on most with the rest of the staff here. I try and expose them to what's the next thing, what's the new thing, $[\ldots]$ and I'm trying to really encourage them to do more of that themselves, you know, to try and push the limits of what they're doing, find what are some alternate solutions, what's something new that's coming up, what's another strategy that'll allow us to get more work done with less effort. [P07]

Fourth, MIPs need to balance what can be done in the museum and what should be outsourced. Research participants described this as a difficult balancing act, since it requires MIPs to weigh potential cost-savings against the benefits of increasing in-house skills. While acquiring the skills, capabilities, and technical expertise to complete information technology projects in-house can take longer than outsourcing, the long-term benefits of doing so can outweigh short-term expenses:

I could just go to a contractor and have them do it, but we don't have the budget, first of all, and also, it's kind of a challenge and I'd like to learn how to do it, same with my assistant. You know, we'd rather learn how to do it ourselves rather than just have the contractor do it, so we'll know how to do it next time. [...] It'll take it a little longer than if we had someone else do it, but it's really important for us to get the skills in-house, since the budget is not getting any bigger, that's for sure. [P10]

Finally, while coping with changing technical capabilities is very important, it is equally important for MIPs to understand whether new capabilities contribute to or detract from the museum's core mission. The research participants stressed the need to consider the true mission and goal of the museum when faced with new technologies and changing capabilities. They stressed the potentially dangerous possibility of becoming focused on technology for technology's sake, and distracted from the museum's overall mission:

The core competency of a museum is not the management of complex technology, it's the creative use of it. [...] A museum cannot afford to sustain full-timers and many 
developers. The industry is changing too fast, and we want to be able to take a boutique approach to get the tools needed when you want them and where you want them. [...] To keep up with everything in the back office of a museum is ludicrous. [P19]

\section{Changing Needs}

As technologies change, the needs of the museum's users change also, as their needs adapt in response to the museum's new capabilities. For MIPs, this establishes a difficult feedback cycle, where new capabilities are developed to meet new needs, and needs evolve as they take advantage of new capabilities. Coping with this cycle of changing needs and capabilities requires MIPs to adapt viewpoints, shifting their perceptions of why they need certain abilities, and changing their attitudes about their role in the museum:

You know we really thought in terms of HTML in the beginning, very simple web pages that didn't involve any scripting. They weren't really relying on dynamic content. [Now] we've stretched that to the point where that same medium is behaving more like a set of applications. It's gotten far more complex. That was around before, but what needed to happen was an attitude shift. We needed to start thinking about how can we make this medium serve the needs of the entire staff. [P07]

This kind of attitude shift is challenging, because it requires a solid understanding of the needs of all users of museum information - needs that not only change over time, but also reflect the desires of many different users, from staff members working in the museum to visitors accessing the museum's resources over the Internet. Several strategies can help cope with these challenges. First, MIPs should have a broad understanding of the museum's current and future needs. According to the research participants, understanding what is going on elsewhere in the museum allows them to do a better job when working on projects with other museum staff members:

Early on in web development, the webmaster would be the person who would write all the HTML. Somebody would say 'Hey, I have this information that goes on the website,' so that would just get written directly into the source code. [Now] there's more of a desire to build systems that will give a web interface and let people kind of update their own content areas of the website, and so I think that means that my role has to be more understanding the more broad view, what the current and the future needs of the departments going to be, so I can build systems that will let them do what they need with their parts of the website. [P06]

Paying attention to information needs across the museum provides MIPs a valuable perspective which can affect the quality of their work. Research participants stressed the danger of information professionals working in museums without understanding what they are doing within the context of the museum:

You just have to actually pay attention to what we're doing, we don't just take [information] and blindly put it up on the website. So it means, you know, understanding what that person is giving us and saying 'Wait a minute, someone else gave us this that conflicts with this information.' So really paying attention to what's happening 
throughout the organization, to make sure that everything, when you sit back and look at it, is a whole picture. So a lot of just paying attention, I think, and trying to be aware of what's going on throughout the museum, not just in our department. [P10]

This perspective is especially important given the rapidity with which museums are changing. Not only are the information needs of museum staff members changing, but the overall mission of the museum evolves as museums adapt to the changing needs of their communities. An awareness of their role in the context of the museum helps MIPs keep up with changing needs and fulfill their job requirements:

Museums are changing so rapidly [...] We're changing from being repositories of collections that have a wow factor to more educational institutions, we're trying to be the voice for so many different people and communities. I think when you get all these changes at once, you sort of get what that means for museums. I think the average person needs to see their job in the context of other jobs at the museum. I've found it's a lot easier for me to do my job and find ways to do my job better, if I understand more about the preservation process and how collections work and how objects are accessioned or de-accessioned, how program people work and how exhibitions are put together and even how partnerships are formed with outside institutions and what that involves. [P03]

Second, MIPs need to assess and evaluate needs and requirements for specific museum projects. Determining user needs while working on information technology projects can be difficult, as users of information resources have a hard time specifying systems requirements and assessing their own information needs. MIPs need skills in working with others to analyze system requirements, assess information needs, and evaluate information systems and practices:

You always need to be able to receive whatever requirements are given to you and be able to query and find out in more detail what the real requirements are. A lot of times people think they're telling you what they need and you need to be able to probe to find out really what's underneath it. I think the requirement of gathering for a specific need is the most challenging part of any information job, because you need to be able to gather that sufficiently, otherwise you can end up creating something or meeting the wrong need or not meeting the need at all. [P11]

While working to identify user needs for specific museum projects, MIPs can take advantage of their broad understanding of the museum's current and future needs to develop more accurate, more timely, or more robust, system requirements. In this way, MIPs help museum employees find new ways to solve problems, possibly even developing systems that can meet not only current, but also future, user needs:

From our direction, we've just been able to say well, we know that what you're asking for is a simple HTML page, but what we'd like to see you get is something more exciting. [...] These really aren't things that the rest of the museum is directly asking for until they know they're possible, and so we do a lot of prototyping here, really get to people to try to throw them into bigger ideas, things that are a little more exciting, things 
that really try to push the boundaries so that hopefully that will keep them happy and keep them, kind of meet their needs for the next few years. [P07]

Third, MIPs need to understand and accept new ways of working with information resources. This is important as museums build new relationships with their visitors in response to changing user needs. As museum visitors embrace new ideas about how museums provide access to information, museum professionals must respond to these changes:

At our museum, we find that a lot of the visitors go to the web first for information about where we are and hours and programs and things like that. So I think that if the general population learns to go to the web instead of the Yellow Pages for more information, then museums are forced to have a web presence, and to pay a lot of attention to what it looks like and how it works and things like that. [P02]

These changes have been particularly dramatic online, especially as the number of online visitors increases to rival or eclipse the number of visitors to the physical museum. According to the research participants, the growing popularity of online museums has increased the number of problems MIPs face:

The fact that twice as many people see our website as come through the museum doors, and that the online store rivals our most popular satellite store revenue, puts a whole other dynamic on what we're doing with the web. It becomes another museum, in a sense, with that many complicated things to deal with. [P04]

Finally, faced with this changing information environment, MIPs need to balance and integrate the changing needs of all users of museum information resources. This becomes especially crucial as MIPs help others in the museum consider the needs of museum visitors and understand how those needs differ from user to user, in the museum and online. Resources need to be repurposed for multiple uses by different types of users, a task that requires new methods of information management and new abilities for understanding information access and use:

Everything has been computerized, or is in the process of being digitized, and people like me are trying to get the public access to it. So there's a big need, I think, to figure out how to integrate collections systems with the visitor use and scholarly use. What's happened is that collections systems are getting to the point where they're going to be useful to other people, and so [we are] figuring out how to integrate the two. [P01]

\section{Changing Expectations}

As technologies change and the role of the museum in the information society evolves, MIPs face the challenge of integrating information resources to meet diverse needs. They need the ability to keep current with changing expectations about the information resources museums possess and methods for making those resources available. Understanding changing expectations goes beyond learning new capabilities and meeting new needs; it means adapting to new ideas about the kinds of information services museums should provide: 
The demand is always growing, or at least it has for the past five years. [...] People are starting to rely on [the IT department] more, and as we face budget cuts, and as we face restrictions on what we can do in other places, instead of printing a brochure, people might think 'Let's put that online instead.' [P07]

The need to adapt to changing expectations extends to the entire museum staff. All museum personnel should try to understand the changing expectations of the museum's users, so that everyone can become involved in implementing new capabilities to meet new needs. Museum employees should not rely solely on MIPs to expand the museum's use of information technologies or to improve access to the museum's information resources:

I think it's very crucial that these initiatives should not start with the [IT] department. Knowledge is out there that will help someone do their jobs better, and of course we can introduce it if they don't know about it. But for the most part it should come from the departments, it should come from the different areas of museum professionals. [P18]

Several strategies for keeping up with changing expectations emerged from the interviews. First, MIPs need to encourage broader communication among museum staff members. By improving communication inside the museum, MIPs will involve all museum personnel in finding solutions to common problems as the needs and expectations of their users change:

Breaking down barriers between IT and other units, to make other units believe that you are on their side, and understand their concerns or even share their knowledge is a very, very difficult concept. [...] This communication stuff-it is so difficult to cross barriers so that you can be really a part of a team. [P19]

Second, MIPs need to encourage museum staff members to share information across the museum. When dealing with daily problems, it can be difficult to share information between museum departments, yet access to information can be a critical factor in the staff's ability to fulfill the museum's mission. It is crucial for museum information professionals to promote technologies and practices that encourage museum staff members to share information:

The thing that we find most, most necessary, the most desired aspect of technology for the greater number of staff people in this museum, is the way of sharing information between departments so that the people who have nothing to do with the mounting of an exhibition can have access to information that is about that exhibition that critically effects their work, as in the education department or the community relations department. There's so much information sharing that has to happen and this is probably true in any type of organization, that when museum departments all focus on a central aspect, such as an exhibition or the collections themselves, that information needs to be as available, as integrated with other kinds of activities, as possible. [P09]

Third, MIPs should become involved in museum projects as soon as possible, especially with information technology projects. The sooner MIPs involve themselves with new projects, the better positioned they are to make a positive impact on these projects, and the more likely other museum personnel will be to involve MIPs in future projects: 
Whenever there's a new project initiated, we would like to get in on it from the beginning. That way have an idea about what they're doing and we can maybe recommend [solutions]. [P12]

Finally, MIPs need to help museum staff members become aware of the potential benefits of integrating information science and museum work. As advanced information technologies are integrated into museum activities, it is important for MIPs to educate other staff about museum informatics. All museum staff members should understand the possibilities and limitations inherent to their information-oriented activities:

Our role is really like helping educate them: 'Why can't you do it this way? Well this is why.' $[\ldots]$ That's always been a big challenge: trying to educate and make sure that the limitations are being understood. I have to work a lot of times with some departments that have never considered themselves that they need to understand [IT], and now it's becoming more of a necessity, like you don't really have a choice anymore. [P10]

The more museum professionals understand the importance of information science and technology in the museum, the more involved MIPs become in museum projects. The more involved MIPs become, the more museum professionals expect from them, especially as people learn what can be accomplished with information technologies:

People expect bigger, faster, flashier, more interactive [...] The more we reach out, the more people expect higher quality and more inclusions in projects, I think it kind of builds on itself. [P12]

Over time, it becomes easier for MIPs to meet changing expectations within the museum. As they encourage other museum employees to push the boundaries of museum technology projects, those employees respond in kind, and everyone become more informed about the possibilities generated by museum informatics:

I think that people in museums today definitely are more aware of some of the possibilities. [...] We find that's always our responsibility to make people aware of some of those things when those ideas come up. Our role is definitely a two-way role. There are very few projects that come in here and get finished without some modifications, without some kind of added insight or added perspective, from our viewpoint, being the people who are really familiar with the technology now, $[\ldots]$ and after a while people start to pick up on these things and start to ask some more informed questions. [P07]

As this cycle builds and spreads throughout the institution, museum professionals learn that they all face common challenges. By helping everyone understand changing expectations inside and outside the museum, MIPs encourage a greater understanding of the role of the museum in the information society. In this way, everyone becomes increasingly aware that all information organizations are working on common problems, whether they are museums, libraries, archives, or any other information organization: 
One thing that I think that I've seen in recent years, what I think is an encouraging trend towards the sort of convergence of information science and library science to impact all cultural heritage endeavors that range from archives to natural history museums. I think that that's a very positive thing, I think that everybody can learn from each other. I think that the skills needed are basically the same across those arenas, and that all of our information is going to end up in one big pot one of these days. [P09]

\section{Discussion: Implications for Museum Information Professionals}

Information professionals are not the only ones aware of the growing convergence of cultural heritage organizations in the information age. As users rely increasingly on online information, they will likely expect to find similar types of resources offered by different institutions. This is especially the case as increased digitization erodes the traditional distinctions between libraries, museums and archives (Rayward, 1998). Thanks to new capabilities, many historical barriers which separated and limited the information those organizations could provide in the past no longer exist. As a result, information professionals are re-evaluating the impact new technologies may have on their ability to fulfill their roles as information service providers.

If museums are to remain relevant for modern visitors, museum professionals must adapt to meet the changing needs and expectations of their users. As users continue to evolve their conceptions of what information today's museums should provide, information professionals working in museums need to remain current with those changes and help other museum professionals survive the necessary shifts in focus, attitude, and philosophy. As museums become more integrated into the information society, and museum professionals and museum visitors become more aware of the information resources museums can offer, the perceptions of information work and roles of information professionals in museums are changing. If researchers are to continue to provide quality research that supports the needs of modern museum professionals, then the research agenda of museum informatics needs to change as well (cf. Jörgensen, 2004).

\section{Changing Perceptions}

The challenges and coping strategies presented in this paper can be seen as different aspects of changing perceptions about the nature of museum information work and the role of information professionals in museums: who they are, what they do, and the services they provide.

Perceptions of information work in museums have changed as MIPs learn more about the roles they are expected to play in museums and the contributions they are expected to make towards achieving the museum's core mission. Confronted with the challenges described above, MIPs have reacted by re-evaluating their notions of what it means to be an information professional in a museum. They have learned to adapt to externally imposed requirements, an approach which has enabled MIPs to meet the changing capabilities, needs, and expectations they encounter on the job.

Perceptions of information work in museums have changed as MIPs educate other museum professionals and museum visitors about their evolving responsibilities. In light of the challenges facing modern museums, it is crucial that MIPs play an active role in guiding these changes. Given their knowledge, experience, and responsibilities, MIPs are ideally situated to guide 
changing perceptions of information work in museums. If MIPs only react to changes imposed by others, then situations may arise that are harmful to both MIPs and museums. As active participants, MIPs have the unique opportunity to adapt their own skills to meet new needs and redefine their own notions of information work in museums, while simultaneously helping others re-evaluate the value and role of information professionals in museums.

\section{Changing Roles}

To succeed at their jobs, MIPs need to play an active role in guiding the future of information work in museums. In doing so, they will likely find themselves advocating, establishing, and administering information policies - making decisions that may influence entire museums as well as the activities of museum professionals and visitors. Facing such an awesome responsibility may be difficult for many MIPs, requiring them to assert unfamiliar and uncomfortable roles, and placing them in the potentially awkward position of redefining the museum and their own place in it simultaneously.

Despite these difficulties, the task of actively driving museums in a particular direction with respect to information work cannot be left to individuals with no understanding of information science. Few museum employees are as qualified as MIPs to help museum professionals and museum visitors evolve their understandings of the information resources a museum should provide and the role museums play in the information society. To do so, MIPs must establish themselves as the best (and perhaps only) individuals qualified to make decisions about such issues as digitization policies, metadata standards, digital rights management, and so on. MIPs need to take advantage of their unique position to understand changing capabilities, needs, and expectations at an organizational level.

Thus, MIPs assume new roles in museums, where the ability to configure a server or complete a catalog record becomes less important than the ability to identify and solve problems of information access, provision, and communication (cf. Marty, in press). As new technologies emerge and needs and expectations evolve, the physical manifestations (e.g. websites, databases, etc.) of the MIPs' skills may change, but the underlying importance of the skills they offer will not. Specific skills and technologies quickly become obsolete, but the ability to look at the big picture will always be important. The true value of MIPs lies not in their ability to solve individual technology problems; it lies in their ability to comprehend of the future of information work in museums. The challenge MIPs face is to present themselves as individuals with the proven skills and abilities to lead the museum into that future.

\section{Changing Research}

The challenge academics, researchers, and practitioners interested in museum informatics face lies in helping MIPs accomplish these goals. To help MIPS guide museums and play a role in shaping the museum of the future, researchers must ask "big picture" questions that help MIPs understand the changing needs and expectations of all museum users. Despite the recent increase of research in this area (Coburn \& Baca, 2004; Gilliland-Swetland \& White, 2004; Goldman \& Schaller, 2004), there is still much to learn about the information behavior of museum users and how they incorporate museum resources into their daily lives. This lack of knowledge is 
unfortunate, especially as the number of museums offering digital resources to their users increases (Institute for Museum and Library Services, 2002) and the role of information professionals in museums becomes more important (Marty, 2004b).

One potential solution to this problem is to increase the amount of research looking at the "museum in the life of the user." Such a shift in focus may prove difficult, as it is likely that this approach will pose many of the same challenges as studying the "library in the life of the user" (Augst \& Wiegand, 2003; Zweizig \& Dervin, 1977). Yet this perspective may hold the key for helping MIPs answer some of the more difficult questions they face on the job. When providing online access to digital museum resources, for instance, many MIPs are asked whether museums lose significant revenue from users who decide there is no need to visit physical museums if they can access virtual museums online, despite overwhelming evidence that this fear is unfounded (Marty, 2004a; Thomas \& Carey, 2005). That this question continues to vex so many has less to do with financial remuneration than it does with how users of digital museum resources perceive the integration of those resources into the sociocultural fabric of their everyday lives.

Museum informatics researchers need to explain the role museum information plays in the lives of museum users at all levels. If researchers are to help MIPs serve the needs of their users, they must be able to answer questions such as: Why do individuals desire access to digital museum resources? What is the relationship between digital and physical museum resources for those users? How can enhanced gallery devices (such as audio guides or tablet computers) help individual visitors interface with or make sense of museum exhibits? How can museum websites blur boundaries (e.g. through podcasting or personal digital collections) between online and inhouse museum resources? Only by answering these (and similar) questions will researchers be able to help MIPs understand how changing capabilities have affected their ability to meet the needs and expectations of museum visitors and museum professionals. To do so, researchers and professionals will need to work together, asking and answering questions important to everyone interested in the future of museum information work.

\section{Conclusion}

The lack of studies about the information behavior of MIPs presents a call to arms for all researchers interested in the future of information professionals working in museums and other cultural heritage organizations. In addition to the questions raised above about the use of information resources in museums, there remain many open questions about MIPs themselves that could be answered by future studies. One line of inquiry concerns the educational opportunities students should pursue to prepare for future careers as information professionals in museums (Marty, 2005). Research is needed to identify the relative importance of information science for current and future museum professionals, and to assess the continuing education possibilities available for individuals currently working as MIPs who wish to keep their skills and abilities up-to-date for twenty-first century museums.

Another possible line of inquiry concerns the growing dependence of MIPs on their abilities to work with online repositories of shared collections data or digital images. Researchers have only just begun evaluating and analyzing questions about how information professionals in museums make use of such resources (Gilliland-Swetland \& White, 2004). As more museums contribute 
data to these repositories and collaborate in their creation and development, it becomes crucial that researchers develop mechanisms for assessing the abilities of MIPs to participate in such projects in ways that produce positive results for museums. In particular, it will be important to study the abilities of MIPs to encourage museums to participate in these initiatives, to determine what data standards will be used by their museums in relation to these projects, and to promote the proper use of those standards among all professionals working in their own museums. How MIPs can best participate in data sharing initiatives and encourage others in their museums to do so in a timely and appropriate manner remains an open question worthy of future study.

Finally, as museum visitors and museum professionals evolve their expectations of the information resources museums and other cultural heritage organizations should provide, MIPs face serious challenges as they adapt to changing capabilities and strive to meet the changing needs and expectations of museum users. The coping strategies identified in this paper enable them to deal more effectively with changing capabilities, needs, and expectations while making use of information resources, tools, and technologies on the job. By pursuing further research into these challenges and coping strategies, museum informatics researchers will gain the knowledge they need to understand the changing perceptions of museum information work and the changing roles of information professionals in museums. By using this knowledge to guide new research projects, museum information researchers will be able to help all museum professionals better understand the future of the museum in the information society.

\section{Acknowledgements}

The author would like to acknowledge the hard work and dedication of the museum professionals who participated in this research. Without their contributions, this project would never have been possible. The author would also like to acknowledge the efforts of his research assistant, Anna Wilcoxon, who is a master's student in the College of Information, as well as the contributions of the anonymous reviewers who helped improve this manuscript.

\section{References}

Allen, N. (2000). Collaboration through the Colorado digitization project. First Monday, 5(6). Retrieved August 1, 2005, from http:/www.firstmonday.org/issues/issue5_6/allen

American Association of Museums. (1994). Careers in museums: A variety of vocations. Washington, DC: American Association of Museums.

Augst, T., \& Wiegand, W. (2003). Libraries as Agencies of Culture. Madison, WI: University of Wisconsin Press.

Bearman, D. (1994). Strategies for cultural heritage information standards in a networked world. Archives and Museum Informatics, 8, 93-106.

Bearman, D. (1997). New economic models for administering cultural intellectual property. In K. Jones-Garmil (Ed.), The wired museum: Emerging technology and changing paradigms (pp. 231-266). Washington, D.C.: American Association of Museums. 
Bearman, D. \& Trant, J. (2000). Introduction to special issue on museum informatics. Journal of the American Society for Information Science, 51, 3-4.

Bennet, N., \& Sandore, B. (2001). The IMLS digital cultural heritage community project: A case study of tools for effective project management and collaboration. First Monday, 6(7). Retrieved August 1, 2005, from http://firstmonday.org/issues/issue6_7/bennett

Bernier, R. \& Bowen, J. (2004). Web-based discussion groups at stake: The profile of museum professionals online. Program: Electronic Library \& Information Systems, 38, 120-137.

Blackaby, J. (1997). Integrated information systems. In K. Jones-Garmil (Ed.), The wired museum: Emerging technology and changing paradigms (pp. 203-230). Washington, DC: American Association of Museums.

Bowen, J., \& Filippini-Fantoni, S. (2004). Personalization and the Web from a museum perspective. In D. Bearman \& J. Trant (Eds.), Museums and the Web 2004 (pp. 63-78). Toronto, CA: Archives and Museum Informatics.

Burkaw, G. E. (1997). Introduction to museum work. Walnut Creek, CA: Altamira Press.

Cannon-Brookes, P. (1992). The nature of museum collections. In J. Thompson (Ed.), Manual of curatorship (pp. 500-512). London: Butterworth.

Cameron, F. (2003). Digital Futures I: Museum collections, digital technologies, and the cultural construction of knowledge. Curator, 46, 325-340.

Carson, C. (2001). Copyright and the Dead Sea Scrolls: A case study of the intellectual property issues involved in the research use of collections. Spectra, 28(3), 18-30.

Case, M. (Ed.). Registrars on record. Washington, DC: American Association of Museums.

Chadwick, J., \& Boverie, P. (1999). A survey of characteristics and patterns of behavior in visitors to a museum Web site. In D. Bearman \& J. Trant (Eds.), Museums and the Web 1999 (pp. 154-162). Pittsburgh, PA: Archives and Museum Informatics.

Coburn, E., \& Baca, M. (2004, June). Beyond the gallery walls: Tools and methods for leading end-users to collections information. Bulletin of the American Society for Information Science and Technology, 30(5), 14-19.

Cunliffe, D., Kritou, E., \& Tudhope, D. (2001). Usability evaluation for museum Web sites. Museum Management and Curatorship, 19, 229-252

Danilov, V.J. (1994). Museum careers and training: A professional guide. Westport, CT: Greenwood Press. 
Dyson, M. \& Moran, K. (2000). Informing the design of Web interfaces to museum collections. Museum Management and Curatorship, 18, 391-406.

Economou, M. (1998). The evaluation of museum multimedia applications: lessons from research. Museum Management and Curatorship, 17, 173-187

Evans, J., \& Sterry, P. (1999). Portable computers and interactive multimedia: A new paradigm for interpreting museum collections. Archives and Museum Informatics, 13, 113-126.

Galani, A., \& Chalmers, M. (2002). Can you see me? Exploring co-visiting between physical and virtual visitors. In D. Bearman \& J. Trant (Eds.), Museums and the Web 2002 (pp. 31-40). Pittsburgh, PA: Archives and Museum Informatics.

Gillard, P., \& Cranny-Francis, A. (2002). Evaluation for effective Web communication: An Australian example. Curator, 45, 35-49.

Gilliland-Swetland, A., \& White, L. (2004, June). Museum information professionals as providers and users of online resources. Bulletin of the American Society for Information Science and Technology, 30(5), 23-27.

Glaser, J.R., \& Zenetou, A.A. (1996). Museums: A place to work. Planning museum careers. London: Routledge.

Goldman, K.H., \& Schaller, D. (2004). Exploring motivational factors and visitor satisfaction in on-line museum visits. In D. Bearman \& J. Trant (Eds.), Museums and the Web 2004 (pp. 223-235). Toronto, CA: Archives and Museum Informatics.

Grant, A. (2001) 'Cataloguing is dead: Long live the cataloguers!' The changing role of museum information professionals in mediating museum knowledge. mda Information, 5(3), 1922.

Haley Goldman, M., \& Haley Goldman, K. Whither the Web: Professionalism and practices for the changing museum. In D. Bearman \& J. Trant (Eds.), Museums and the Web 2005 (n.p.). Toronto, CA: Archives and Museum Informatics.

Hamma, K. (2004a). The role of museums in online teaching, learning, and research. First Monday, 9(5). Retrieved August 1, 2005, from http://firstmonday.org/issues/issue9_5/hamma

Hamma, K. (2004b, June). Becoming digital. Bulletin of the American Society for Information Science and Technology, 30(5), 11-13.

Harms, I. \& Schweibenz, W. (2001). Evaluating the usability of a museum Web site. In D. Bearman \& J. Trant (Eds.), Museums and the Web 2001 (pp. 43-54). Pittsburgh, PA: Archives and Museum Informatics. 
Hermann, J. (1997). Shortcuts to Oz: Strategies and tactics for getting museums to the Emerald City. In K. Jones-Garmil (Ed.), The wired museum: Emerging technology and changing paradigms (pp. 65-91). Washington, D.C.: American Association of Museums.

Hertzum, M. (1998). A review of museum websites: In search of user-centered design. Archives and Museum Informatics, 12, 127-138.

Hooper-Greenhill, E. (1992). Museums and the shaping of knowledge. London: Routledge.

Institute for Museum and Library Services. (2002). Status of technology and digitization in the nation's museums and libraries 2002 report. Retrieved August 1, 2005, from http://www.imls.gov/reports/techreports/intro02.htm

Koot, G-J. (2001). Museum librarians as information strategists. INSPEL, 35, 248-258.

Jörgensen, C. (2004). Unlocking the museum: A manifesto. Journal of the American Society for Information Science and Technology, 55, 462-464.

Knell, S. (2003). The shape of things to come: Museums in the technological landscape. Museum and Society, 1 (3), 132-146.

Kravchyna, V. \& Hastings, S. (2002). Informational value of museum Web sites. First Monday, 7(2). Retrieved August 1, 2005, from http://firstmonday.org/issues/issue7_2/kravchyna

Lanzi, E. (1998). Introduction to vocabularies: Enhancing access to cultural heritage information. Los Angeles, CA: Getty Trust Publications

Lord, B., \& Lord, G. D. (1997). The manual of museum management. Walnut Creek, CA: Altamira Press.

MacDonald, G.F. (1991). The museum as information utility. Museum Management and Curatorship, 10, 305-311.

Marty, P.F. (1999). Museum informatics and collaborative technologies: the emerging sociotechnological dimension of information science in museum environments. Journal of the American Society for Information Science, 50, 1083-1091.

Marty, P.F. (2004a). The changing role of the museum webmaster: Past, present, and future. In D. Bearman \& J. Trant (Eds.), Museums and the Web 2004 (n.p.). Toronto, CA: Archives $\&$ Museum Informatics.

Marty, P.F. (2004b). The evolving roles of information professionals in museums. Bulletin of the American Society for Information Science and Technology, 30(5), 20-23. 
Marty, P.F. (2005). So you want to work in a museum? Guiding the careers of future information professionals in museums. Journal of Education for Library and Information Science, 46, 115-133.

Marty, P.F. (in press). Meeting user needs in the modern museum: Profiles of the new museum information professional. Library \& Information Science Research.

Marty, P.F., Rayward, W.B., \& Twidale, M. (2003). Museum informatics. Annual Review of Information Science and Technology, 37, 259-294.

Marty, P. \& Twidale, M. (2004). Lost in gallery space: A conceptual framework for analyzing the usability flaws of museum web sites. First Monday 9(9). Retrieved August 1, 2005, from http://www.firstmonday.org/issues/issue9_9/marty

Müller, K. (2002). Museums and virtuality. Curator, 45, 21-33.

Ockuly, J. (2003). What clicks? An interim report on audience research. In D. Bearman \& J. Trant (Eds.), Museums and the Web 2003 (n.p.). Toronto, CA: Archives and Museum Informatics.

Orna, E., \& Pettitt, C. (1998) Information management in museums. Aldershot: Gower.

Peacock, D. (2002). Statistics, structures, and satisfied customers: Using Web log data to improve site performance. In D. Bearman \& J. Trant (Eds.), Museums and the Web 2002 (pp. 157-166). Pittsburgh, PA: Archives and Museum Informatics.

Perkins, J. (2001). A new way of making cultural information resources visible on the Web: Museums and the open archive initiative. In D. Bearman \& J. Trant (Eds.), Museums and the Web 2001 (pp. 87-92). Pittsburgh, PA: Archives and Museum Informatics.

Rayward, W.B. (1998). Electronic information and the functional integration of libraries, museums and archives. In E. Higgs (Ed.), History and electronic artefacts (pp. 207-224). Oxford: Oxford University Press.

Reed, P.A., \& Sledge, J. (1988). Thinking about museum information. Library Trends, 37, 220231.

Rinehart, R. (2001). Museums and the online archive of California. Spectra, 29, 20-27.

Roberts, A. (2001). The changing role of information professionals in museums. mda Information, 5(3), 15-18.

Sarraf, S. (1999). A survey of museums on the web: Who uses museum websites? Curator, 42, 231-243. 
Schwarzer, M. (2001a). Graduate training in museum studies: What students need to know. Washington DC: American Association of Museums.

Schwarzer, M. (2001b, July/August). Art and gadgetry: The future of the museum visit. Museum News, 36-41.

Strauss, A., \& Corbin, J. (1998). Basics of qualitative research. Thousand Oaks, CA: Sage.

Teather, L., \& Wilhelm, K. (1999). Web musing: Evaluating museums on the Web from learning theory to methodology. In D. Bearman \& J. Trant (Eds.), Museums and the Web 1999 (pp. 131-143). Pittsburgh, PA: Archives and Museum Informatics.

Thomas, W.A. \& Carey, S. Actual/virtual visits: What are the links? In D. Bearman \& J. Trant (Eds.), Museums and the Web 2005 (n.p.). Toronto, CA: Archives \& Museum Informatics.

Washburn, W. (1984, February). Collecting information, not objects. Museum News, 5-15.

White, L. (2004). Museum informatics: Collections, people, access, and use. Bulletin of the American Society for Information Science and Technology, 30(5), 9-10.

Zorich, D. (1997). Beyond bitslag: Integrating museum resources on the Internet. In K. JonesGarmil (Ed.), The wired museum: Emerging technology and changing paradigms (pp. 171-202). Washington, DC: American Association of Museums.

Zorich, D. (1999). Introduction to managing digital assets: Options for cultural and educational organizations. Los Angeles, CA: Getty Trust Publications.

Zweizig, D., \& Dervin, B. (1977). Public library use, users, uses: Advances in knowledge of the characteristics and needs of the adult clientele of American public libraries. Advances in Librarianship, 7, 231-255. 